\title{
9. Work
}

Among the participants in this study, work was rarely the only reason for migration and was frequently, as Nour Saber would say, "un prétexte." Despite this, most research participants also came to Switzerland in order to complete professional training, to gather work experience, to advance their careers, or - although in this sample this was the exception - simply to enhance their personal and their family's financial situation. In the biographical accounts, the workplace plays a central role as a site of self-actualization and failure, of recognition and rejection, of integration and exclusion, of pressure and freedom, and of professional advancement and deskilling. Encountering and overcoming work-related obstacles in order to 'make it' and reinvent oneself successfully in a foreign country, is as much a source of pride and self-confidence as professional setbacks are a trigger for existential fears, self-doubt, insecurity, depression, and social isolation. This chapter engages with these different aspects of queer migrant women's work biographies and exposes why they have to be read in conjunction with their sexual biographies.

Chapter 9.1 engages with the workplace as a site of self-realization and recognition. Tied to their mostly high levels of education and social status, interviewees expect their professional activities to promote self-development, rather than merely providing a regular income. Importantly, professional self-realization and sexual self-fulfillment are seen as interlocking factors in the process of establishing a 'good life' in the diaspora. Chapter 9.2 addresses experiences of exclusion in the workplace, which contrast imaginations of the workplace as a site in which to establish contact with other people, and as an arena in which to earn social recognition. Being excluded from work altogether because of deskilling and unemployment significantly aggravates feelings of alienation and isolation; this will be discussed in Chapter 9.3. Chapter 9.4 engages with interviewees' strategies of communicating (or not) their sexual orientation at work. Finally, Chapter 9.5 illuminates work from a different perspective altogether. It examines work as a topic of intra-familial conflicts, and shows how interviewees frame concessions they make when negotiating their education and career with their parents as a 'trade-off' that enables them to assert another aspect of their Selves they consider to be much more imperative - their dissident sexualities and love lives. 


\subsection{Work as a Site of Recognition, Self-Realization, and Integration}

Work represents an important arena of recognition - particularly so in the context of migration, where the overall success of a migration project is often contingent on employment and/or professional success (Baghdadi and Riaño 2014, Mecheril 2000). The importance of a positive work experience is clearly confirmed in the biographical narratives generated in the context of this study. Work is seen as a key site for 'integrating and of achieving a 'good life' in the diaspora, which accordingly becomes threatened when work-related problems arise. In its significance for the migration project, the process of establishing oneself professionally is only paralleled by the processes of coming to terms with one's non-conforming sexuality, building a fulfilling relationship, and succeeding in forging meaningful social ties in the new country. As the narratives suggest, these different areas of life are co-constructive and have to be read in conjunction.

Among the participants in this study, expectations towards work were generally high. Financial goals or career opportunities were thereby secondary to the importance of work as a site of personal development and fulfillment. This attitude towards work is tied to the elevated social status most research participants inhabited, or inhabited before migration, mirroring specific ideals of self-realization and social norms. The perspective on work expressed by Teresa Ruiz' following statement is exemplary of many other interviewees' professional self-perception:

Vielleicht bin ich in der Phase gewesen jetzt in diesen ersten zehn Jahren, ich habe wirklich immer etwas machen müssen um mich weiter zu entwickeln. Vielleicht hört es mal aufjetzt, sag ich jaja nach dieser Ausbildung höre ich auf, sage ich immer. Aber dann später ist mir wieder langweilig (lacht).

Maybe I have been in this phase in these first ten years, I really always needed to do something to advance my personal development. Maybe it will stop at some point now, that's what I keep saying, yes yes after this training I'll stop, that's what I always say. But then later I get bored again (laughs).

-Teresa Ruiz

As her diplomas were not recognized in Switzerland, and because she did not speak German, Teresa Ruiz had to start her career "from scratch" when she came here in her early twenties. It took the specialized nurse a decade and a divorce from a husband who wanted to forbid her to continue school to catch up and establish herself professionally. She communicates a sense of pride in having succeeded against all odds: Now Teresa Ruiz is a popular team leader in a health institution in Basel. Although she continues to suffer from bouts of homesickness, a sense of arrival is palpable in her narrative. Eleven years ago, she resolved "to integrate"; retrospectively, the central stepping stones in achieving success in this process were re-launching her career, assuming a lesbian identity, establishing a fulfilling relationship, and learning German (see Chapter 5.1).

Achieving a good 'work-life balance' was an important aspect of personal development. This priority is related to the exceptionally stressful work situations that many of the participants in this study were exposed to. Reflections on health issues related to their work were a recurrent theme across accounts, and apart from deskilling and 
unemployment emerged as the most significant obstacle in interviewees' work biographies. Many interviewees suffered from stress, burnout, or depression due to experiences of social isolation at work or underemployment - for instance Siti Mohd Amin, Augusta Wakari, Pilar Gómez, Ayesha Umar, Charlotta Sembiring, Leyla Haddad, Nour Saber, Nara Agayeva, and Ramiza Salakhova.

Siti Mohd Amin, who like Teresa Ruiz has been living in Switzerland for eleven years, has spent most of her time working long shifts as a chef de cuisine in different "bumping" restaurants in the city of Bern. She says that often she does not get home before half past one in the morning, after helping the kitchen crew clean up and then finishing administrative tasks like planning menus and placing orders. Even though she does not record the many hours she works in the office each week on her timekeeping file (!), she always accumulates a considerable amount of overtime. While this allows her to go back to Malaysia for extended visits each year, her long and unusual working hours and her constant state of exhaustion crucially contribute to her acute social isolation. After work Siti Mohd Amin is too tired, or it is too late, to go out, and during the day she mostly sleeps until she has to go back to work. "There is no life, is only working and working, working place and home, you know?", she says. Her strong desire to establish a common life with a partner in Switzerland has not been realized; as discussed in Chapter 5.2, Siti Mohd Amin's two Malaysian partners live in the Middle East and in Malaysia respectively, and neither are prepared to join her. The lack of a partner to share everyday life with is the main reason why she would like to return to Malaysia. However, this plan is also fueled by a need to "relax." Siti Mohd Amin would like to open a small restaurant in Malaysia, not to make a lot of money but "just to survive [...] the daily, the monthly." After an intense decade of working in Swiss restaurants she feels tired. Siti Mohd Amin's work experience in Switzerland has therefore been highly ambivalent. On the one hand, work has been a site of self-development. As she emphasizes, her professional activities have enabled her to develop her cooking, leadership, and administrative skills, and she says that beyond these practical things she has learned to "stand on my own leg." At the same time, work also appears as a site of integration in the most negative sense. As a laborer, Siti Mohd Amin is 'integrated' to the point of becoming entirely consumed by her exploitative work conditions, which have rendered it impossible for her to establish a social life outside the work context.

Throughout this chapter, other cases will be touched upon in which work-related health issues played a role. What is common to these accounts with regard to work as a site of self-advancement is that the interviewed women consider the strategies they have developed to deal with health issues at work important learning processes. Interviewees who have been affected by burnout and other work-related problems assess their crises and the ensuing restructurings of their lives as integral and sometimes eventually positive parts of their personal growth, rather than as personal or professional failures. Respecting one's own needs and health to install not only a fulfilling but also a sustainable (work) life hence emerges as an important aspect of personal development and of a 'good life' in Switzerland.

Personal development on the one hand and unsatisfactory work conditions or unemployment on the other are also the main drivers of some interviewees' ambitions to become self-employed. As Augusta Wakari, cook in a university canteen, states: "If 
I have my own business, I can be much more creative in this. [...] In the end since I have always someone above me, I'm not really growing, I'm not really creative, 'cause whatever they [=superiors] said, at the end I would do it." The lack of variety and self-determination aggravates the stress Augusta Wakari's job entails. She is not given enough employees to fulfill the tasks she is responsible for and feels that her inability to fight or say no - which she ascribes to her Asian culture - has caused her to disregard her personal needs for too long. When we met for the first interview, Augusta Wakari had just started taking anti-depressants and was suffering from severe burnout. When we met for the second time, she had quit her job. ${ }^{1}$ Other interviewees had resorted to selfemployment as well in order to become active entrepreneurs in the face of deskilling, lack of recognition and unemployment. The main driver of these projects - which in her study of migrant women's self-employment projects in Switzerland, Raphaela Hettlage (2014) aptly terms "biographical projects" - is the desire for self-actualization and recognition. Due to the racialized mechanisms of exclusion structuring the Swiss labor market and work environments, this desire is often not met.

Especially interviewees who have come to identify as lesbians while living in Switzerland conceptualize the development of their professional and sexual identities as parallel and interdependent processes, which are both perceived to be central to achieving a 'good life' in Switzerland. Beatriz Krais says that it was her success as a sports instructor in Switzerland that provided her with the self-assurance she needed to become more confident in other areas of life, such as, especially, her sexuality.

Moi j'aime mon travail, et c'est vrai que je suis bien dans ce que je fais, et c'est vrai que ça m'a beaucoup aidé que je mûrisse plus, j'étais quand même pas mal timide [...]. Des gens qui me connaissent un peu ils disent 'C'est incroyable, comme tu changes par rapport à la sécurité à l'assurance' [en donnant des cours]. [...] Maintenant je me sens bien dans ma vie aussi privée quoi, et justement je pense qu'un influence l'autre parce que là je suis encore mieux au fitness qu'avant, même si avant j'étais bien dans ce que je faisais, mais parce que maintenant c'est plus facile au niveau privé, je parle de ma vie normalement, que ce soit avec mes collègues, que ce soit avec mes amis tout ça [...]; si on n'est pas bien d'un côté après ça va pas de l'autre (rire), tôt ou tard ça va pas de l'autre.

I love my work, and it's true that I'm good at what I do in my job, and it's true that this helped me a lot to mature more, I was after all quite timid before [...]. People who know me a little they say 'It's incredible how you change with respect to self-assurance' [when teaching classes]. [...] Now I feel good in my private life, too, and I really think that one influences the other because now I'm even better in the fitness classes than before, even if before I was already good at what I was doing, but because now it's easier with respect to my private life, I speak about my life normally, be it with colleagues or friends and everything [...]; if you're not doing well on one side then the other will not work either (laughs), sooner or later the other will not work either.

-Beatriz Krais 
The sense of self-assurance she experiences when teaching classes has been fundamental for Beatriz Krais in gaining self-confidence in the process of coming to terms with her same-sex desire and assuming a lesbian identity. She can now "speak normally" about her private life, having to a great extent conquered the sense of shame she experienced at first when she realized that she loved women. Vice versa, having acknowledged her homosexuality has bolstered her confidence in what she does professionally. Beatriz Krais concludes the interview with the words "C'est vrai que je me suis bien integrée" - "It's true that I have integrated myself well." As in the case of Teresa Ruiz, professional success and the establishment of a sustainable partnership have played an important role in this process. At the same time, the interdependencies between work and love life Beatriz Krais addresses renders this 'good life' brittle: If one of these areas of life is dysfunctional, "the other will not work either." Augusta Wakari confirms this perspective as she explains what pictures she envisions taking for this research project:

The first picture will be my home, where there's ]oëlle [her partner] in it (laughs), yeah. And my second one, it will be my working place. Those two just have to work, well 'cause otherwise when one of that is not working, then I'm totally- how can I say? [...] Disrupted, exactly. I'm not function, actually (laughs), not function well at all when one of it is not working [...].

-Augusta Wakari

As with heterosexual migrant women (Baghdadi 2008), for the interviewed queer migrant women fulfilling work, professional recognition, and participation in society bear a significance that extends well beyond work life, affecting interviewees' general selfesteem, their sense of belonging, and their health. However, as will be discussed in the next two sub-chapters, queer migrant women are particularly exposed to negative experiences at, or exclusion from, work. By implication, this also bears a heightened danger of destabilizing other aspects of their Selves and lives.

\subsection{Failing to Connect at Work}

Just as work represents an arena of recognition and personal development, it also appears as a site of exclusion. These exclusions take many forms. In this sub-chapter, experiences of exclusion at work are addressed; the next sub-chapter then addresses exclusion from work in the form of deskilling and unemployment.

As mentioned earlier, many interviewees migrated to Switzerland alone, without a partner or family members. Traveling alone, the workplace typically represented the first opportunity to get in contact with people in Switzerland. Especially in the period immediately after arrival, the social aspects of work were of particular importance. However, interviewees' accounts demonstrate that even in the long run, contacts made at work mostly failed to develop into meaningful relationships. This is exemplified in Charlotta Sembiring's case. She describes her arrival in her research group after her involuntary transfer from a Dutch university to the University of Bern as follows: 
If foreigner you come here, who's the first people you meet, you come to the office, right? [...] So yeah, if you cannot talk about daily life with your colleagues and it's completely isolated, and we don't talk about daily life with our colleagues, 'cause they don't [...]. I don't know why, but it's just like, it's just the normal way for them because they talk about it at home. And when you're at work, you work, you talk about your work and that's quite, well of this particular culture of Switzerland. [...] You don't go to your colleagues' house, right? You don't meet their families, you don't meet even their partner, [...] it's just for many years you may have been working with some people but you have no idea how do their partners even look like, not to mention their daily life there. -Charlotta Sembiring

The efforts Charlotta Sembiring has undertaken over the past two years to make friends with her team colleagues have largely failed:

I was really trying to embrace the situation and being part of it and okay just do it [...] and so I was inviting my colleagues to come over for dinner, and they liked it very much but nobody invited me back. [...] I mean, because we were always polite but I don't find the feeling of connection.

-Charlotta Sembiring

From these experiences Charlotta Sembiring concludes that "before talking about being lesbian I think really we are considered being foreigners." Similar experiences of exclusion at work were a recurrent theme across accounts, as was often the attendant view that being a foreigner shapes work life in Switzerland in much more profound ways than being a lesbian. However, interviewees rarely attributed these failures to connect to work colleagues directly to racism or xenophobia in Swiss work environments, but instead predominantly ascribed these experiences to the specific characteristics of Swiss communication and work culture. Interviewees above all highlighted Swiss colleagues' general reserve, their pronounced avoidance of conflicts, and their strict distinction between work and private life. The latter further manifested itself in a perceived lack of interest in interviewees' wellbeing, which was a source of particular consternation and estrangement. Language issues were understood as a further prominent obstacle, as Swiss people were perceived to lack willingness to speak in a common language that was not their own.

After months of fruitless efforts, Charlotta Sembiring eventually turned away from her own to other research groups, where she was eventually able to forge some connections with other immigrant researchers. She shares this strategy of connecting to other 'foreigners' with other interviewees like Maria Borkovic, who works in the Marketing and Communications Department at the headquarters of a multinational firm in Basel. After several failed attempts to connect to Swiss lesbians at lesbian events in Basel, in her disappointment Maria Borkovic refocused her efforts to forge social contacts in her workplace:

The only place you know [in] which I can talk [to] and meet people, it's my working place you know. [...] There also it's easier for us because they are also foreigners, [...] so we all mix, we don't have barriers between us since we are all foreigners, I also know how do they feel, they live here like two years and they have none of Swiss friend. So 
[the Swiss] all have you know these cliques between them and this [the workplace] is the only place which I can like have friends. Outside is just like impossible.

-Maria Borkovic

However, seeking social contact among fellow 'foreigners' rather than the 'unapproachable Swiss' is not a guarantee for success either. Maria Borkovic qualifies her own statement later in the interview, admitting that her relationships to her international work colleagues have remained distant: "It's like we're really good colleagues and really like sort of friends in the working place but everything beyond just doesn't exist, they separate it, they have own families their own friends, boyfriends, girlfriends, whatever," she says. Although Maria Borkovic does not make this explicit, her sense of unbelonging in these circles eventually also centrally hinges on her sexual orientation: She has begun to avoid the events her work colleagues regularly attend, because she perceives them to be populated by "creamy people," who are characterized by an excessive display of heteronormativity.

Many interviewees had given up trying to forge friendships in the workplace. Maria Borkovic decided to abort her struggle to find friends in Switzerland altogether: "I don't care, its' just, if the life will bring, you know, somebody to get to know, it will bring, I will just not push it [any more]." Ayesha Umar, who in the interviews emerges as an extroverted, proactive, enterprising, and adventurous person that understands herself as someone who likes to be immersed in new cultures and learn new languages, concludes in the face of her prolonged yet futile attempts to connect to her work colleagues and other people in Switzerland: "Die Schweiz ist wirklich nicht mein Land" - "Switzerland is really not my country." In an attempt to improve the quality of her social life, she recently moved to the French-speaking part of Switzerland, in the hope that the Romands will be more sociable and open since they are culturally more similar to the French.

In contrast to these accounts highlighting the problems that emerge for international workers in the face of Swiss communication and work culture, some interviewees explicitly link experiences of exclusion at work to their sexual orientation. Barbara Wiegand, for instance, attaches her sense of alienation at work to what she terms "das heterosexuelle Spiel" - "the heterosexual game." As she assesses ironically:

Ich bin ja so superschlau (selbstironisch) und analysiere alles, aber bis ich gewisse ganz banale Sachen merke da könnten Jahrhunderte verstreichen (schmunzelt), und ich bin [dann] völlig erstaunt. Was ICH eben nicht draufhabe ist das heterosexuelle Spiel [bei der Arbeit]. Das merke ich lange nicht dass es um das geht, ich bin meistens sachorientiert und personenbezogen. [...] Mir kommt es nicht sofort in den Sinn. Und dann wenn ich es merke bin ich mal enorm gelangweilt, und dann fange ich mir an zu überlegen 'Oh Gott ja, es-gut sie finden mich komisch ja logisch (lacht), ich habs gecheckt.'

I am so super smart (self-ironically) and analyze everything, but until I realize certain entirely banal things, centuries could pass (smirks), and then I am completely astonished. What I miss out on is the heterosexual game [at work]. It takes me a long time to figure out that this is what it's about, I am mostly matter-of-fact and person-related. [...] It doesn't occur to me immediately. And then when I realize it I am enormously bored, and then I start to think 'Oh Cod yes it- okay they think I'm strange, yes that 
makes sense (laughs), I got it.'

-Barbara Wiegand

This statement pointedly describes the sense of exclusion generated by the implicit heterosexuality of the workplace. Not realizing that the "heterosexual game" is in operation at work, or consciously opting out of it, excludes people with alternative sexualities from the social mechanisms that are the lubricants of a successful work life, such as flirtation, gossip, or certain work-related events. This not only causes queer people to be left out but may also represent a hindrance to satisfying teamwork and individual promotion (Valentine 1993). Hence, Barbara Wiegand's analysis reifies queer geographers' contention that ritualized workplace performances not only reflect the gendered division of labor but are also firmly rooted in a heterosexual matrix (Bell and Valentine 1995b, McDowell 1995).

The fact that few research participants directly related their experiences of exclusion at work to racism, xenophobia, sexism, or homophobia in Switzerland does not allow for the converse conclusion that these issues have been conquered, or that mechanisms of exclusion at the workplace are 'merely' based on differing communication and work cultures. Instead, the rather scarce explicit mention of racism, for example, in queer migrant women's accounts must rather be understood in the context of Switzerland as a space of "raceless racism" (see Chapter 1), as well as in the context of persistent structural disadvantages in the kind of workplaces most participants in this study worked in. Similarly, homophobia is hard to address in a context in which Switzerland represents itself, and becomes represented, as a homo-friendly space, despite ongoing violence and structural discrimination against sexually dissident people (see Chapters 2.2, 3.4.2, and 3.4.3). In interview excerpts discussed earlier, interviewees struggled to uncover, name and categorize the reasons for their experiences of exclusion and their sense of alienation at work and in other areas of their everyday lives. At the same time, these diffuse discriminations are notoriously difficult to dissect. As shown by the earlier discussion of the instance in which Barbara Wiegand attempted to glean from the "village idiot" what it was about her that vexed her fellow villagers most - her identity as a woman, an intellectual, a 'foreigner,' or a lesbian (see Chapter 7.1) - for individuals who are marginalized in multiple ways, it is often a source of great insecurity not to know the exact reason why they are being discriminated against. Pilar Gómez had a similar experience at work. When we met for the first interview, she had been suspended from work for a month, and had already been notified that she was going to be dismissed from the telecommunication firm she had been working for as a secretary for twenty years. She became the target of serious bullying led by her new (young, male) superior. This dismissal was going to place Pilar Gómez in a highly precarious situation. She was single and could hence not count on a partner to support her financially in the long run; and as a woman of 44 it was not going to be easy for her to find a new job (she did eventually find a new job five years later, from which she has since been dismissed again). In the interviews, Pilar Gómez states that she believes that her much younger and "macho" superior could not endure that she was not laughing at his sexist and homophobic jokes, or, on a deeper level, that she was his senior, a woman, and a lesbian. Like Barbara Wiegand, it unsettles Pilar Gómez not to be able to pin down the exact source of 
his hostility. While Pilar Gómez' experience shows that there is indeed also continued blatant sexism and homophobia in Swiss workplaces (the jokes), it also mirrors Barbara Wiegand's experience of not being able to definitively trace these experiences of exclusion back to any of these '-isms' - racism, sexism, or heterosexism.

Most of the time, discriminatory acts play out just below the surface and are therefore hard to pinpoint. Julia Nentwich (2007) analyzes discursive constructions of what has been termed 'new racism' and 'new sexism' in Swiss work environments. Nentwich argues that new discursive practices have grown from the context in which explicitly discriminatory statements - especially in the workplace - have become taboo in Switzerland. Since social differences must be upheld nonetheless, they are now being reproduced through a set of discursive maneuvers that render discrimination invisible while at the same time perpetuating it. 'New racist' discourses in everyday interactions are, for instance, characterized by disclaimers ("I'm not a racist, but..."), particularization ("X is a good guy, but generally..."), and by excuses ("This may sound a little politically incorrect, but let's face it..."), which seek to position the speaker as non-racist but are immediately followed by a discriminatory statement. Such moves of defensiveness, keeping face, and positive self-representation on the part of the speaker work towards mitigating the exposure of the speaker as a racist while reinstalling social difference. Nentwich's analysis has since been underscored and contextualized by emerging Swiss critical race scholarship, which identifies Switzerland as a space of "raceless racism" (see Chapter 1). 'New sexist' discursive practices work along similar lines. Here discursive strategies include denying inequality between the genders by presenting gender equality as already installed; describing instances of discrimination as isolated incidents; blaming others for persisting inequalities (school, family, the education system, etc.); or pleas to be 'realistic' about gender quotas within organizations given the 'objective' lack of qualified women (Nentwich 2007). Other scholars have made similar arguments with respect to homophobia at the workplace. While lesbians and gay men continue to be exposed to direct discrimination such as dismissal based on sexual orientation, subtle acts of exclusion performed by work colleagues or superiors are much more frequent (Schneeberger et al. 2002, see also Valentine 1993 and 2000 [1998], Waaldijk and Bonini-Baraldi 2006).

In sum, explicit discrimination based on gender, race, or ethnicity and sexuality has, to a certain extent, yielded to subtle discriminatory acts and structural discrimination that are hard to address as they operate underground. Affected interviewees were left with a vague sense of alienation and isolation that they were unable to pinpoint the source of, and which they rarely explicitly related to racism, xenophobia, sexism, or homophobia. Instead, the tendency was to ground this sense of estrangement in the Swiss culture of work and communication, which interviewees perceived as specifically adverse to foreigners because it for instance included the refusal to speak a common language (or, in German-speaking Switzerland, the refusal to speak high German instead of Swiss German dialect), or to address private matters at the workplace. 


\section{3 "Romeo and Juliet would have killed each other long ago": Being Excluded from Work}

Lack of professional recognition was a recurrent theme across accounts, as was unemployment, which many respondents had experienced at some point since coming to Switzerland. Nour Saber, Efra Mahmoud, Charlotta Sembiring, Nara Agayeva, and Ramiza Salakhova all suffer(ed) through extended periods of unemployment. ${ }^{2}$ This subchapter revisits Nara Agayeva and Ramiza Salakhova's account, which illustrates the ways in which exclusion from work fuels social isolation, and explores how exclusion from work is co-constitutive with other forms of marginalization.

Because their application process for asylum in Switzerland is ongoing, Nara Agayeva and Ramiza Salakhova have not been allowed to work in Switzerland for over four years. ${ }^{3}$ While their successful flight to Switzerland brought the couple great relief, the prolonged asylum application process, and especially the attendant work restriction proves to be a further touchstone for them, individually and as a couple. In the interviews, Nara Agayeva appears as a highly motivated, ambitious, entrepreneurial, resourceful, and active person. Not being allowed to work for such extended periods of time has had detrimental effects on the sports instructor. "Man muss sehr starke Nerven haben und psychisch sehr stabil sein um das alles zu überleben" - "You need to have strong nerves and be very stable psychologically to survive all this," she states. She would like to "be among people" and "do something." Instead, she and her partner mostly find themselves confined to their small apartment with a book or the TV, unable to go to places because there is no money to spend, and tired of the same walk along the local creek. As Ramiza Salakhova describes a typical rainy day in the Agayeva-Salakhova family home:

Aber manchmal [...] das Wetter ist nicht gut und wir sitzen ganzen Tag zusammen, sie kann dort sitzen, ich kann hier sitzen, dann ich gehe ich sitze dort, sie sitzt hier, und Kind ist auch zu Hause [...] und ich denke das ist wirklich erstaunlich, und wir streiten nicht, sie nervt mich nicht [...].

But sometimes [...] the weather is not good and we sit together the entire day, she can sit there, I can sit here, then I go and sit there, she sits here, and child is also at home [...] and I think this is really remarkable, and we don't fight, she doesn't get on my nerves [...].

-Ramiza Salakhova

This seemingly harmless story in which nothing happens once more unmasks the violent spatiality of the 'borders within' (see Chapter 8) that discipline queer migrant

2 Charlotta Sembiring's period of unemployment started after the interviews and extended over several years. She eventually became partially self-employed, and has recently found part-time employment.

3 Note that this is an unusually long period of time, as asylum seekers are usually allowed to start working six months after entering Switzerland. I have not been able to establish the reason for this exceptional treatment. 
bodies. The restrictions of asylum procedure and the attendant work ban exerts considerable pressure on Nara Agayeva and Ramiza Salakhova's relationship. "Hätten Romeo und Julia Möglichkeit, zusammen vierundzwanzig Stunden in vier Jahren zusammen in einem Wohnung wohnen, würden sie sich schon längst umgebracht haben" - "If Romeo and Juliet had had the possibility to live together in one apartment for twenty-four hours for four years, they would have killed each other long ago," Nara Agayeva laughs, adding in seriousness that she and her partner have created "ein Denkmal der Liebe" - "a monument of love" because they still love each other in the face of these adverse circumstances.

During these four years, the greatest challenge for Nara Agayeva has been "nicht auf einen Platz zu stehen, einfach sich entwickeln" - "not to stand still, just to keep on developing," as she repeatedly emphasizes. The couple taught themselves German within the first few months of arriving in Switzerland and immersed themselves in Swiss and European culture by reading European literature (especially the feminist classics) and by watching local TV news and documentaries.

When I visited the couple for the second time, Ramiza Salakhova had just obtained her temporary status as a refugee. Suddenly, she was not only allowed but required to work, and she was under a great deal of stress about having to organize the necessary documents to register at the local governmental employment office. These events upset the established family structure, as this is not how the couple had envisioned their roles. As Nara Agayeva states:

\begin{abstract}
Also ich meine jetzt ich muss das Geld verdienen. Ich habe eine Familie und ich muss das Geld verdienen. Und ja, ich bin ja doch nicht wie hundert []ahre alt] und ja, nicht alt, und ich kann es machen und das Problem ist dass man mich [nicht] lässt. Machen lässt. Weil schon dass sie [die Familie] alle brauchen Unterstützung, und das Kind muss jetzt dann studieren. Ramiza braucht auch ihre Ausbildung [...]. Und dafür, hätte ich Möglichkeit arbeiten, dann könnte es funktionieren. Aber so muss sie jetzt laufen, Diplom [von Ramiza] anerkennen lassen, gleichzeitig irgend wo arbeiten ja weiss ich ja nicht, putzen oder so, weiss ich ja nicht.
\end{abstract}

Well I mean now I have to earn the money. I have a family and I need to earn the money. And well, it's not like I'm a hundred years old and yes, I'm not old, and I can do it, the problem is that they [don't] let me. Let me do it. Because already that they [the family] all need support, and the child has to start her studies. Ramiza also needs her professional training [...]. And for that, if I had the possibility to work, then it could work. But as it is now she has to run, have her diplomas recognized, work somewhere at the same time I don't know, cleaning or something, who knows.

-Nara Agayeva

Not being able to work becomes a double legacy for Nara Agayeva: As someone who defines herself through what she does professionally, the work prohibition not only denies her access to a crucial source of identification and self-realization, but bars her from assuming her intended role in her family. She has been working tirelessly towards creating a space to make this family possible ever since she and her partner became a couple, organizing visas, planning their flight, supporting her partner who was abused by her husband, and she considers it natural to assume the position of the breadwinner, at least until her partner has completed her desired professional training. 
In her efforts to enhance the family's situation, Nara Agayeva has in fact already started to work in Switzerland as a volunteer instructor for a local sports team. Her team has already celebrated a number of successes at local and international competitions; a local newspaper has published an article about her; and she has gleaned a free car and laptop from the sports club. "Also ich habe schon ehrgeizige Ziele" - "I mean, I have ambitious goals," she says about her plans with her team, proudly stating that the number of club members has increased since she started training the team. "Und die kommen nicht einfach in Schule, sie kommen auf [meinen] Namen" - "And they don't just come to the school, they come because of [my] name," she points out.

While Nara Agayeva relates these achievements with pride, she clearly classifies them as preparation rather than arrival. "Aber jetzt möchten wir leben. Zu beginnen" - "But now we would like to live. To start living," she says, "wir sind nicht [mehr] zwanzigjährige Mädchen" - "we are not twenty-year-old girls [anymore]." The voluntary work only occupies her for a couple of hours each week. She would like to start earning money to be able to support her partner's professional training and their daughter's education, and envisions completing an advanced vocational training. Before she can do this, however, she has to continue to wait for an answer from the Federal Migration Office; until then, her wishes continue to be deferred. As Ramiza Salakhova explains the importance of a positive asylum decree for her own professional life:

Dieses Jahr habe ich ein Traum gesehen, dass ich eine Erlaubnis Aufenthalt hier in der Schweiz bekommen-Oooh! [...] Ich hab gestanden ich sagte 'Nara! Nara! Was habe ich gesehen!' (lacht) und ich denke es war das erste mal, als ich so einen Traum gesehen habe, ich habe irgendwelche Papier bekommen dass ich darf, dass ich kann und will helfen [...].

This year I saw in a dream that I got a residence permit here in Switzerland- Oooh! [...] I stood I said 'Nara! Nara! What have I seen!' (laughs) and I think it was the first time that I saw a dream like this, I got some paper that I'm allowed to, that I can and want to help [...].

—Ramiza Salakhova

While in their home country, Ramiza Salakhova's husband had forbidden his wife from educating herself or working in her original profession, and Nara Agayeva's professional skills became dispensable as girls were gradually excluded from sports lessons. For both women, being able to stay in Switzerland is thus not about consumption and passivity - as commonly held prejudices against asylum seekers in Switzerland would have it - but about self-realization, social recognition, and participation. "To begin living" not only means to feel safe but to be of use and to become a full-fledged and contributing member of society, which is importantly also framed in terms of waged work.

The emotional and economic repercussions Nara Agayeva and Ramiza Salakhova have suffered due to their enforced unemployment parallels those experienced by other research participants who are, or have been, subject to unemployment. While no other research participant has experienced as radical and absolute an exclusion from the labor market as Nara Agayeva and Ramiza Salakhova, other situations are a more or less direct result of immigration procedure as well. This is the case for Nour Saber, who due to regulations attached to the Partnership Act is forced to continue living in a town 
remote from any job opportunity that might do justice to her professional qualifications (see Chapter 8). Moreover, as discussed above in the context of the bullying Pilar Gómez was exposed to, unemployment can be a result of discrimination grounded in an opaque conglomerate of rejections based on different aspects of queer migrant women's identities.

Finally, the workplace appears as a site of exclusion in the sense that some interviewees have been excluded from adequate work. As discussed at the outset of this chapter, interviewees expect work to be meaningful and challenging, and to foster personal development. Accordingly, interviewees who are exposed to deskilling and find themselves in jobs lacking challenges find it hard to maintain their motivation. After an extended period of unemployment, Efra Mahmoud eventually found a job, albeit one that does not match her qualifications. While she appreciates that this employment enables her to live without debts for the first time in a long time, the tasks she has to perform are not satisfying:

Ich mache nur die Sache auf die Datenbank [...], das ist kein Problem aber es ist langweilig, ich mache nix, ich denke nicht, ich muss einfach-ist alles tactac, und ich mache das nicht gerne. Ich hätte gerne zum Beispiel auch verstanden um was die Sache geht [...], ich bin nicht eine Maschine man sagt und es ist so du machst so und das ist fertig. Ich bin nicht so. [...] Ich habe gedacht es ist nur Arbeit zum Celd verdienen, aber zum Arbeit zum gerne machen oder so, das ist nicht mein Traumjob so.

I only do stuff in the database [...], that's no problem but it's boring, I don't do anything, I don't think, I just have to- everything is tactactac and don't like doing that. I would for instance have liked to understand what the topic is [...], I'm not a machine you tell and it's like that and you do that and finished. That's not the way I am. [...] I thought it's only work to earn money, but in order to like doing the work or something, this is not the job of my dreams.

-Efra Mahmoud

As many accounts in which deskilling plays a role showed, like complete exclusion from the labor market and discrimination at work, deskilling significantly affects self-esteem and can induce health problems and destabilize other areas of life.

I would like to conclude this sub-chapter by embedding its findings in wider Swiss migration scholarship. Experiences of exclusion and isolation in the workplace, deskilling, and unemployment confirm the findings of the rapidly growing body of research investigating the work biographies of skilled migrant women in German-speaking countries incited by Encarnación Rodríguez Gutiérrez' groundbreaking Intellektuelle Migrantinnen (Rodríguez Gutiérrez 1999; for Swiss studies see e.g. Baghdadi 2008, Riaño 2003b, and Riaño and Baghdadi 2007, see Chapter 2.1.4). Since such mechanisms of exclusion have also been documented in heterosexual migrant women's work experiences, the question remains: In what ways do queer migrant women's experiences of exclusion at work differ from those of heterosexual immigrant women?

These differences are significant. First, for queer migrant women, experiences of exclusion at and from work may critically aggravate the sense of disconnection and so- 
cial isolation they experience in other important areas of life, especially in the family of origin and in the lesbian or in their diasporic communities. In other words, queer migrant women do not have the same access to 'fallback' social networks as heterosexual migrant women often do. Such multiple exclusions increase the significance of the workplace as a site of social connectivity and financial security and aggravate repercussions if these connections fail to materialize or unemployment occurs.

The second point was already mentioned earlier (Chapter 6) and addresses the fact that the option of resorting to the role of wife and mother in case of professional failure is not available to queer migrant women to the same extent that it is to their heterosexual counterparts. While being relegated to the home is usually not an ideal option for skilled heterosexual migrant women either, at least the performance of stereotypical gender roles offers some social recognition. By contrast, queer women often face rejection when presenting their baby projects to their families (at least at first; again, no data could be gathered as to what happens after these children's births, see Chapter 6.2).

Third, queer migrant women's experiences of exclusion at and from work may, on first sight, seem unrelated to sexual identity, as skilled heterosexual migrant women, too, often experience difficulties in forging connections to their Swiss work colleagues, or to obtain employment in the first place. However, they do not additionally have to negotiate heteronormativity and homophobia at work, which has its own exclusionary effects.

Finally, on a side note: The experiences of exclusion discussed in this sub-chapter chiefly concern interviewees who did not have any social contacts in Switzerland when they came here. Others, who came to Switzerland quite early in their lives and have been living here with their families, or who migrated here for their bachelor studies already, were able to establish social networks before entering work life and are hence not as dependent on being able to forge social contacts at work. At the same time, while the (few) interviewees in this study who have joined a partner or family members in Switzerland have been able to fall back on these contacts, these connections remain fragile, and are never a guarantee of smooth 'integration.' Nour Saber, for instance, who was unexpectedly left by her partner soon after her arrival in Switzerland, now finds herself in a precarious emotional and legal situation.

\section{4 'Coming out' at Work}

'Coming out' at work is a recurrent theme across queer migrant women's biographies. Experiences and positions with regard to communicating one's sexual orientation at work vary widely: While for some sexuality and work is an exceedingly difficult issue, for others it bears hardly any significance. This continuum is the subject of this subchapter.

Work typically concludes the list of the spaces in which interviewees have communicated - or plan to communicate - their sexual orientation. Best friends are typically the first to be brought in to the loop, followed (if applicable) by friends in the lesbian community and elsewhere; only then does 'coming out' to work colleagues or superiors become an issue. (As discussed in Chapter 6, the placement of family in this imaginary 
'sequence of communication' varies.) The position of the workplace on this list goes some way towards demonstrating the lack of trust in Swiss work environments to recognize sexually non-conforming co-workers and employees. As queer scholars' examinations of non-migrant lesbians' and gays' experiences of exclusion in Swiss workspaces have yielded, this sense of distrust remains justified (Rüttimann 2012, Schneeberger et al. 2002).

It should not come as a surprise that interviewees who did not identify as lesbians or who had not made their sexual preference known to friends or family did not communicate their sexual orientation at work either (see Chapter 5.3). Efra Mahmoud, who does not identify as lesbian, says that taking part in a lesbian event would, in theory, be possible for her, but the fear of being seen there by someone from her workplace or the Egyptian diasporic community keeps her away. In her workplace, subtly homophobic quips are frequent, and she is afraid to become the subject of such stereotypes at work.

Other interviewees have not come out at work but are planning to do so at some point in the future. In a twist on the negative perceptions of Swiss work and communication culture discussed above, these women frame Swiss colleagues' reservations and their tendency to separate the private from the professional in exceedingly positive terms, relating it to respect and decency rather than disinterest and distance. It is exactly this - here welcome - containment that allows them to determine the point in time in which to communicate their sexual orientation at work themselves, rather than having it extracted by colleagues' queries into their intimate spheres. As Nara Agayeva states when pondering her plans to come out to the colleagues at the sports club where she works as a volunteer, "Die Menschen sind ja sehr anständig und stellen keine weiteren Fragen" - "The people are very decent and don't continue asking questions." She contrasts this to her and Ramiza Salakhova's experiences in their common workplace in their home city, where persistent questions about one's intimate sphere were daily fare (and where a colleague eventually intruded in their private sphere by telling Ramiza Salakhova's husband that he suspected his wife of entertaining a relationship with Nara Agayeva).

Further, there were interviewees who applied complex communication strategies in the workplace. In these cases, sexual orientation or same-sex partnerships were only selectively revealed to a trusted few, while other co-workers were given elusive answers or lied to if they asked direct questions. Ayesha Umar, Customer Relations manager in a multinational internet firm and living in a registered partnership, explains her communication strategy at work as follows:

Also ich brauche etwas Zeit Leuten vertrauen zu können, etwas Persönliches sagen zu können [...], aber niemand hat mich direkt gefragt. Jemand hat gefragt: 'Bist du verheiratet?' Ich habe gesagt: 'Ja, irgendwie so.' Ich weiss nicht was ich sagen soll, aber ja, ich habe schon ein paar Dinge gesagt, wo die Leute können schon etwas heraus leiten irgendwie aber vielleicht nicht sicher sein. [...] Also weil Englisch sagst du sowieso 'partner,' oder? Das ist so geschlechtsneutral dass niemand weiss. [...] Wenn jemand ist von Ausland, zum Beispiel die Finnin, ich habe gewusst ich kann es erzählen mit ihr und ist kein Problem, oder? Deshalb habe ich es gleich am Anfang erzählt. Also weisst du, es gibt welche von denen ich weiss: Okay, diese Person kann damit umgehen. Mit den Schweizern habe ich immer das Gefühl: Nein, ich kann nicht sicher 
sein, dass die damit umgehen können- als erstes, als zweites weil ich bin eine Frau, Ausländer und habe jetzt eine gute Position in meine Geschäft, oder? Das sind dann diese Faktoren worüber die dann einfach zu viel nachdenken.

Well I need some time to be able to trust people, to say something personal [....], but nobody asked me directly. Somebody asked: 'Are you married?' I said: 'Yes, something like that.' I don't know what to say but yes, I've indeed said a few things that people could guess something from somehow but maybe not be sure. [...] Because in English you say 'partner' anyway, right? This is so neutral with respect to gender that nobody knows. [...] If someone is from abroad, for instance the Finnish woman, I knew I can tell it with her and is no problem, you know? This is why I told her straight from the beginning. Well you know, there are some who I know that: Okay, this person can deal with it. With the Swiss I always have the feeling: No, I can't be sure that they can deal with it- this being the first thing, the second thing being because I'm a woman, a foreigner, and now have a good position in my business, you know? Those are the factors then that they then think about too much.

-Ayesha Umar

The building blocks of Ayesha Umar's communication strategy are ideas about national mentalities (Finnish, Swiss), strategic thinking with respect to her position in the business, and trust. Her linguistic acrobatics (such as relying on English terms to conceal her partner's gender) are expressive of the energy and thought some interviewees invested in navigating their sexual orientation at work, be it out of fear of being targeted by people holding homophobic views or of jeopardizing promotions in highly competitive corporate environments.

Maria Borkovic follows a similar strategy. In contrast to Ayesha Umar, who tends towards a more masculine appearance, Maria Borkovic has carefully constructed a distinctly feminine work persona. She consciously instrumentalizes a feminine appearance and performance to enhance her air of professionalism at work. Stereotypical femininity does not come naturally to Maria Borkovic. She says that she was "really wild" in her adolescence and had to learn 'correct' feminine behavior and appearance when she first started working in "these serious working places," that is, in the corporate world: "Some people cannot sit in front of PC twelve hours and be on conferences calls and be you know very strict and very polite and good-looking, you know you really have to be like tiptop there," she explains.

Maria Borkovic's daily gender performance consolidates her position in the company not only because it abides by the required display of feminine professionalism, but also because it conceals her homosexuality. What is suppressed and hidden during the day requires release in her private life, where Maria Borkovic perceives herself to be a different person. "Strange things can come out of me," she laughs, "people [at work] wouldn't even believe how can I be in private life." She prefers to segregate these two Selves, and social worlds, strictly: "I lead like these two lives completely separate, and after work I don't want to kind of meet these people in my private life because from inside I'm not like really that," she states. As discussed above, she does not feel comfortable in the "snobbish" and reserved atmosphere that marks the spaces in which her 
colleagues meet outside of work, preferring to go to lesbian or alternative parties to dance - even though she has not been able to forge meaningful social connections in these spaces either (see Chapter 5.2.3).

Maria Borkovic has hence created a feminine professional Self that she feels partly alienated from, as it does not correspond to how she perceives herself to be "from inside." This sense of estrangement is connected to the implicated heterosexuality of Maria Borkovic's professional persona, which stands in contrast to her otherwise very self-assured lesbian identity. While Maria Borkovic actively conceals her homosexuality from colleagues, as a kind of private joke she carries her lesbian identity with her at all times: One of the pictures she has contributed to this research shows a rainbow-colored key pendant, attached to which is the key to her flat, but not the one to her office. During work, the former is hidden away in her handbag, and only when she returns home does she take it out. "It's like every day in my hand you know when I open [the door to my apartment], and it really just puts a smile on me." Coming home from work also means coming home to her 'real' gender and sexual identity.

Maria Borkovic's strategy to manage her sexual identity resonates with Gill Valentine's analyses of the spatialities of lesbians' everyday lives. Some of Valentine's interviewees share Maria Borkovic's strategy of performing a lesbian identity in lesbian spaces and at home while performing normative femininity in the workplace, and of creating secret 'queer bubbles' or using secret signs in heterosexual environments, here represented by Maria Borkovic's key pendant (Valentine 1993 and 1995b). Maria Borkovic's account highlights how the heterosexual imperative in Swiss work environments normalizes the expectance of a (hetero)sexualized appearance and performance by women (Salzinger 2007) and demonstrates how queer women become complicit in the reproduction of this expectation by reconstructing stereotypical femininity. The question remains, then, how Maria Borkovic's experiences might differ from those of non-migrant white lesbians. The imagined gay community that is called upon by Maria Borkovic's key pendant strategy marks her desire for a queer home. However, in contrast to many 'Swiss' lesbians who desire lesbian spaces, this home has so far been denied to her. Contrary to her expectations prior to coming to Switzerland, she is not welcomed into the 'lesbian family' in Basel as she had hoped (see Chapter 5.2.3). This eventually renders her 'real' - that is, lesbian - Self just as unstable as the heterosexual identity she performs at work.

A last note on the subject of the fear some interviewees express about jeopardizing their position at work by revealing their sexual orientation: This fear was particularly pronounced in the accounts of those who work in a 'sensitive' line of work and especially concerns women like Maria Borkovic, Nara Agayeva, or Natascha Schild, who either work in competitive corporate work environments, or who are in charge of children as teachers or trainers and are hence concerned about parents' reactions (see also Rüttimann 2012 on homosexual teachers in Switzerland). Furthermore, one interviewee who works in the field of human rights and has to travel widely is cautious about 'coming out' in her professional environment as her destinations include countries in which homosexuality is banned by law.

Other interviewees are irritated by the suggestion that their sexual orientation requires 'disclosure' at all. Some prefer to speak about their sexual orientation upon re- 
quest only and then attempt to answer in an unexcited and "natural" way. As Leyla Haddad relates:

Wenn mich jemand beim Schaffe [bei der Arbeit] fragt, ja und dann der Freund, und nachher sage ich, 'Nein, ich habe keinen Freund, ich habe eine Freundin, ' und versuche sehr natürlich mit dem Thema, also wenn jemand fragt, 'Nein ich habe eine Freundin' und nachher es geht weiter, also nicht jetzt noch da noch gross erklären [...].

If someone asks me at work, yes and what about the boyfriend, and then I say: 'No, I don't have a boyfriend, I have a girlfriend,' and I try to be very natural about the topic, so if someone asks, 'No I have a girlfriend,' and then things move along, I don't really start explaining a lot [...].

—Leyla Haddad

"Du hast schon nachher so den Stempel vom Exoten" - "Afterwards you are stamped as an exotic," Leyla Haddad adds, but corrects herself and says that she is anyway already perceived as an exotic before exposing herself as a lesbian, "aber irgendwie so als angenehme Exotin" - "but somehow like an agreeable exotic." Leyla Haddad grounds this agreeable sense of exoticism in "this kind of liveliness" - "dieses Lebendige" that she thinks people locate in her as a Lebanese, which she identifies as a quality that many Swiss people lack but miss. However, Leyla Haddad's exoticism becomes too much to stomach once her lesbian identity is - 'additionally' - revealed. Barbara Wiegand relates a similar experience of 'additive exoticism' in her workplace: "[Ich könnte] zugeben dass ich einfach lesbisch bin, und was wär dann? Wenn sie mich JETZT schon komisch finden, undsoweiterundsofort. [...] Ich finds eine ZUMUTUNG dass ich so etwas überhaupt denken muss" - "[I could] admit to being lesbian, and then what? If they think I'm weird NOW, and so on. [...] I consider it an IMPOSITION that I have to think such a thing in the first place." In contrast to Leyla Haddad, Barbara Wiegand refrains from communicating her sexual preferences at work: "Es GEHT sie nichts an" - "It IS none of their business."

Generally, few of the interviewees who had come out at work had experienced explicitly negative reactions to their disclosure. Most interviewees did not even mention in their narratives how their 'coming out' was received, but merely stated that they communicated their homosexuality at work. After some time, Charlotta Sembiring's colleagues did not even seem to remember that she was a lesbian - or did not register or take seriously her initial declaration. However, as discussed at the outset of this chapter, we cannot conclude from this relative absence of reports of negative reactions to coming outs that homophobia is absent from workspaces in Switzerland. Interviewees invest a great deal of energy and worry in deciding whether, when, and to whom to come out at work, and many are afraid of becoming subject to homophobia or of jeopardizing their professional position and career, and go to great lengths to conceal or 'manage' the revelation of their sexual orientation in the workplace. These fears are very real. To ascribe them to internalized homophobia or previous experiences with homophobia alone would fall short of a comprehensive analysis. As Efra Mahmoud, Pilar Gómez, and others report, homophobia is present in Swiss workplaces, even if it only surfaces quite rarely in its most blatant forms. Negotiating this persistent homophobia alongside 
the other mechanisms of exclusion queer migrant women face based on their gender, ethnicity, and age poses a major challenge that prompts worry, consumes energy, and requires the development of multifarious strategies in order to protect one's personal needs and professional wellbeing.

\section{5 "I'll just get the degree and then they'll leave me alone": Work as a 'Trade-off' in Intra-familial Negotiations}

This last sub-chapter discusses work from an entirely different perspective. Like sexuality, work is negotiated through the family of origin. As I argue in the ensuing discussion of Leyla Haddad's narrative, these two areas of conflict within the family are highly contingent on one another. This is because daughters strive to establish an overall balance between following their own needs and desires and meeting their parents' expectations; between being independent adults and their parents' daughters; between feeling guilty and giving in; between breaking away and staying in touch. Within these negotiations, interviewees' 'choices' in terms of how to live out their homosexuality influences their communication strategies with their families. As interviewees tend to frame their same-sex desires as 'givens,' this generates pressure on them to 'at least' live up to their parents' expectations with respect to other areas of their lives, such as their education and career.

The character and urgency of families' and interviewees' expectations with regard to education and profession are closely tied to family habitus. Most interviewees' parents had an academic or entrepreneurial background, which exerted pressure on their daughters to establish and maintain meaningful and adequately prestigious professions and positions - although this pressure is often only implicit. As Leyla Haddad muses about her own former expectations regarding her professional life: "Man weiss gar nicht mehr ist es von aussen [=Eltern] oder ist es doch das was ich von mir erwarte, es wird so ein Knäuel" - "You don't know anymore is it from the outside [=parents] or is it what I expect from myself after all, it all gets balled up." Leyla Haddad's account exemplifies this process of balancing the relationship to one's parents, and the effects this pressure can have on career choices and work lives.

Growing up in Beirut in the 1970s, the noise of bombings was such an integral part of Leyla Haddad's everyday soundscape that when she first came to Switzerland, she experienced the silence - "in which you could hear ants snore" - as threatening. Leyla Haddad's mother is a Swiss citizen, and Leyla Haddad's family accordingly traveled to Switzerland from time to time to visit her parents. However, in three instances (all during Leyla Haddad's childhood), the Lebanese civil war escalated while the family was visiting Switzerland, preventing them from returning for a year or more each time. In one such instance, Leyla Haddad stayed in Switzerland at her grandparents' alone. When she returned to Lebanon a year later, she had forgotten how to speak French, English, and Arabic, and was not able to communicate with her father and brother. To catch up at school and relearn all the languages, she received extra attention after school, "ein auf Leistung getrimmtes Kindlein" - "a little child tailored to perform," is how she describes herself. Finally, Leyla Haddad's mother decided to stay in Switzerland 
with the children while her father returned to Lebanon. As the director of a state institution, he was a distinguished member of society; Lebanon is where he had a career, a reputation, and status in his extended family (of which he was, according to Leyla Haddad, "a bit of a patriarch"). At the same time, as a man with an Arab background at the age of fifty, he was aware that it would be next to impossible for him to launch a second career in Switzerland.

For the next few years, everyday life at the Haddads' in Switzerland centered around the news on TV, where they would sometimes catch a glimpse of their father's apartment in central Beirut during reports about the latest bombings. Whenever Leyla Haddad and her brother could not bear to watch the news any more, her mother 'guilt-tripped' the siblings, telling them that they were obliged to watch, since it was thanks to their father working there that they were able to lead a life of comfort, safety, and peace. Leyla Haddad felt guilty, but her mother's reproaches stood in stark contrast to how Leyla Haddad felt: She was very unhappy, missed her father, and felt "extremely homesick." The sense of guilt she felt in regard to her father was multiplied when she realized in her teens that she is attracted to women:

Mein Vater der hat irgendwie sein Leben unter diesen Bomben und er ist auch entführt worden, [...] er hat das alles gemacht, dass wir hier in Frieden leben können, und ich habe mich so schuldig gefühlt, habe gedacht ja ich entspreche halt nicht dem was er erwartet hat.

My father he somehow has this life under these bombs and he was also abducted, [...] he did everything for us to be able to live in peace here, and I felt so guilty, thought well I just don't live up to his expectations.

—Leyla Haddad

Accordingly, Leyla Haddad did not tell her parents about her homosexuality, but one day she accidentally left a letter on the table addressed to her parents. In it she wrote about her homosexuality, her sense of guilt, and also expressed suicidal thoughts. That same evening, Leyla Haddad's mother, uncharacteristically clad in jeans, turned up unexpectedly at the alternative women's bar where Leyla Haddad was tending bar that night. "Sie habe sich nachher Sorgen gemacht, ich habe mir etwas angetan oder so, aber man hat dann nachher nie hingesessen, meine Mutter ist nicht jemand wo man nachher hinsitzt und nachher redet man über das, sie hat einfach das zur Kenntnis genommen" - "She said she had been worried that I had hurt myself or something, but we never sat down afterwards, my mother is not someone you sit down with together afterwards and then you talk about it, she just acknowledged it." However, Leyla Haddad's mother recurrently remarks on her daughter's dissident sexuality: "Meine Mutter hat dann mehr so in Form von verletzenden Bemerkungen mir zu spüren gegeben, dass ich eigentlich nicht so rausgekommen bin, wie sie es sich gewünscht hätte" - "My mother would then let me know more in the form of painful remarks that I hadn't turned out the way she had wished." When Leyla Haddad's father fell ill, her mother blamed her for not meeting his wishes: "Der Papi, der wäre so gern Grossvater geworden" - "Dad, how much he would have liked to become a grandfather."

Leyla Haddad is sure that her mother told her father about the letter and her homosexuality, but he never uttered a word about it for as long as he lived. Nevertheless, she remains grateful that he silently condoned her way of life: 
Und ich muss sagen ich bin heute recht froh dass mein Vater dort irgendwo grosszügig gewesen ist und mich das hat leben lassen, er hätte ja mich auch können- weiss auch nicht, er hat das mal einmal gesagt als ich noch so auf der Suche gewesen bin habe ich mich mit einem Typ eingelassen [...], und einmal war es mal noch ein Dealer gewesen, ein algerischer Dealer. Nein, als der [Vater] das gehört hat [...] hat er gesagt, (energisch) 'Tu vas arreter sinon je t'amenais au Liban,' hat wirklich so-darum habe ich immer Angst gehabt ihm zu sagen ich sei lesbisch, 'Hey hopp auf Libanon hä, heiraten gehen' (lacht), ist mir recht geblieben.

And I must say I today I'm quite glad that my father was generous in a way and let me live this out, I mean he could have- I don't know, he said this once when I was still finding my way I got involved with a guy [...], and another time it was a drug dealer, an Algerian dealer. No, when he [her father] heard that [...] he said, (French, resolutely) 'If you don't stop this I'll bring you to Lebanon,' he really like- therefore I was always afraid to tell him I'm lesbian, 'Hey, off to Lebanon with you, eh, to marry' (laughs), this [incident] really made an impression on me.

—Leyla Haddad

Despite her fear and her deep sense of guilt it has never been an option for Leyla Haddad to concede to her parents' expectations with respect to her relationships. However, in order to be able to maintain her sexual freedom she felt she had to sacrifice her professional freedom:

Was ich [...] habe durchziehen können ist wirklich das mit dem lesbisch, dort habe ich wie gemerkt, das will-das kann- meine Eltern die können noch so toben, ich lasse mich nicht irgendwie in ein Schema [...]. Dort ist für mich klar gewesen solange ich ihnen [beruflich] das mache was sie von mir erwarten können sie mir das wie nicht nehmen.

What I [...] was really able to follow through with was the thing about being lesbian, there I realized that I don't want- can't- my parents can rant all they want, I won't let myself [be] put into a schema...]. There it was clear for me that as long as I do for them [professionally] what they expect they can't like take that from me.

-Leyla Haddad

Everybody in Leyla Haddad's family and their entire social environment in Lebanon has an academic background (except for her brother). "Und darum hat man noch mehr Erwartungen in mich gesteckt" - "and this is why they invested even more expectations in me," Leyla Haddad surmises. Striving to win her parents' recognition, against adverse circumstances she fought her way into the gymnasium. Upon completing school, she discarded her desire to study art, convincing herself that, as her parents said, she would gain more independence by studying medicine.

Despite persistent doubts, she pushed through her studies. "Komm, dann mache ich das Ticket und nachher lassen sie mich dann in Ruhe" - "Come on, I'll just get the ticket [=degree] and then they'll leave me alone," she told herself. However, the pressure failed to ease off when she entered the professional arena, and it is only when the time had come to decide whether to pursue a leading position years later that she realized that she had been working against herself, "immer etwas gegen aussen zu sein versuchen, das nicht immer 
dem entsprochen hat was ich innen bin" - "always trying to be something outwardly that has not always corresponded to what I am on the inside." At this point, she realized that she was not cut out for work that demands such a high level of competitiveness and performance: "Ich bin nicht der Karrieretyp" - "I'm not the career type."

This eventually led to a severe burnout. Leyla Haddad's ensuing process of acknowledging that a career change was inevitable ("Ich muss meine Haut retten" - "I have to save my skin") was marked by more guilt and fear of being pushed away by her parents. "Ich habe wirklich lange Angst gehabt ok, das mit dem Lesbischsein haben sie in Kaufgenommen, aber [nur] solang ich als Ärztin [arbeite]" - "For a long time I was really afraid okay, they accepted my being a lesbian, but [only] as long as I [work] as a doctor." It was only after a long period of time that she eventually concluded: "Irgendwie habe ich gemerkt, nein gut, sie haben mich auch noch als Lesbe gern gehabt und jetzt werden sie mich sicher auch noch gern haben" - "Somehow I realized, well no, they still liked me as a lesbian and now they will surely still like me."

When she eventually told her mother, her mother accepted the decision to abandon her career (her father, already ill at the time, did not get involved in these negotiations). Leyla Haddad felt liberated. When her father died, and due to the disappointment she perceived to have brought her parents, Leyla Haddad felt obliged to take on the responsibility of settling her father's complex affairs in Lebanon. Overall, Leyla Haddad continues to be grateful to both her parents for not disowning her based on her sexual difference, and later her professional choices. "Ob das jetzt das Libanesische ist oder nicht" - "Whether this is now the Lebanese thing or not," she considers the tie between parents and children to be unique. Despite the conflicts she has had with her parents, she perceives herself to be a person with a distinctive "sense of family" ("Familiensinn"): "Meine Eltern, das ist für mich etwas vom Wichtigsten" - "My parents are one of the most important things for me." A statement that is substantiated by the fact that her relationship to her parents is undisputedly the key theme of her narrative.

In the context of this study, Leyla Haddad's story is exceptional because it is shaped by wartime experiences. The constant fear for her life or the life of faraway parents and siblings and the sense of insecurity in her own home defies comparison. Despite (or perhaps because of) the extraordinariness of her biography, Leyla Haddad's narrative crystalizes with a particular urgency how the sense of guilt towards parents with respect to one's dissident sexuality is balanced by 'trade-offs' with respect to education and work. Like Leyla Haddad ("My parents can rant all they want, I can't let myself [be] put in a schema"), other interviewees equally conceptualized their decision to live out their homosexuality less as a choice than as an inevitable fact which, in contrast to other parts of their lives, they experience as non-negotiable and imperative. In order to counterbalance filial disobedience with their love lives, in several cases efforts were made to accommodate parents' expectations with respect to careers at least. However, as Leyla Haddad's narrative testifies to, the underlying belief that concessions in professional life are easier to make than concessions in matters of love may turn out to be self-deceptive and eventually put one's wellbeing at risk. 